\title{
Non-Invasif Termometer:Temporal Artery Thermometer (TAT) Terintegrasi dengan Electronic Medical Recordsebagai Peringkat Teratas Metode Pengukuran Suhu pada Bayi dan Anak: Kajian Literatur
}

\author{
Sugiarti \\ Fakultas Ilmu Keperawatan Peminatan Keperawatan Anak, Universitas Indonesia, Indonesia, \\ Email: sugi.itsuka@gmail.com
}

\begin{abstract}
Non-Invasive Thermometer: Temporal Artery Thermometer (TAT) Integrated With An Electronic Medical Record as Top Ranking of Temperature Measurement Method in Infants and Children. Fever in children caused the high use of healthcare facilities. The majority of parents (90\%) recognized paracetamol as an antipyretic for children, and only $36.7 \%$ of parents who receive the antipyretics were prescribed. Excessive parental concern can lead to aggressive practices harmful to children, such as over dosage of antipyretic use. Accurate temperature assessment was important for early detection of fever, nursing clinical decision, medical diagnosis, and the need for specific laboratory tests. TAT is a new innovation and alternative in the field of child nursing as a detector of fever in children. TAT comes in an automatic form connected to the monitor's vital sign, and integrates with electronic medical records, in order to meet the demanding use of advances in electronic medical records on temperature measurements. Comfort, accuracy, sensitivity, and convenience TAT also carries the concept of nursing atraumatic care and Family Centered Care (FCC). Child nurses in Indonesia need to improve service quality by learning new technologies, and applying existing evidencebased.
\end{abstract}

Keywords: Temperature, TAT, Fever, EMR

\begin{abstract}
Abstrak: Non-Invasif Termometer: Temporal Artery Thermometer (TAT) Terintegrasi dengan Electronic Medical Record sebagai Peringkat Teratas Metode Pengukuran Suhu pada Bayi dan Anak: Kajian Literatur. Demam pada anak menyebabkan tingginya penggunaan fasilitas pelayanan kesehatan. Mayoritas (90\%) orang tua mengenal parasetamol sebagai antipiretik untuk anak, dan hanya $36,7 \%$ orang tua yang mendapatkan antipiretik tersebut berdasarkan resep dokter. Kekhawatiran orang tua yang berlebihan dapat memunculkan praktik agresif berbahaya pada anak, seperti over dosis penggunaan antipiretik. Penilaian suhu yang akurat penting untuk deteksi awal terhadap demam, keputusan klinis keperawatan, diagnosis medis, serta perlu tidaknya dilakukan pemeriksaan laboratorium spesifik. TAT menjadiinovasi dan alternatif baru di bidang keperawatan anak sebagai pendeteksi demam pada anak. TAT hadir dalam bentuk terkoneksi otomatis pada monitor vital sign,dan terintegrasi dengan electronic medical record, dalam rangka memenuhi tuntutan penggunaan kemajuan catatan medis elektronik terhadap hasil pengukuran suhu. Kenyamanan, keakuratan, sensitifitas, dan kemudahan TAT juga mengusung konsep keperawatan anak yaitu a traumatic care dan Family Centered Care (FCC). Perawat anak di Indonesia perlu meningkatkan kualitas pelayanan dengan mempelajari teknologi baru, dan menerapkan evidence based yang ada.
\end{abstract}

Kata kunci: Suhu, TAT, Demam, EMR

Perubahan cuaca yang ekstrim terjadi saat ini, menyebabkan imunitas atau daya tahan tubuh seseorang menjadi menurun. Mengingat sistem kekebalan tubuh anak yang masih dalam proses perkembangan, menjadi hal yang wajar jika demam lebih sering terjadi pada anak-anak dari pada orang dewasa. Demam adalah salah satu gejala klinis yang paling sering ditangani oleh dokter spesialis anak dan tenaga kesehatan lainnya, merupakan persentase kejadian kasus yang paling sering ditemui pada unit gawat darurat, kira-kira sepertiga dari semua kondisi penyakit terjadi pada anak-anak (Barbi et al, 2017; Sullivan \& Farrar, 2011). Di Indonesia penderita demam sebanyak $465(91.0 \%)$ dari 511 ibu yang memakai perabaan untuk menilai demam pada anak mereka, sedangkan sisanya yaitu sekitar 9\% saja yang telah menggunakan termometer (Setyowati, 2013). Data Dinas Kesehatan Provinsi Lampung tahun 2013 
menyebutkan bahwa demam pada anak usia 1-14 tahun mencapai 4.074 anak dengan klasifikasi 1.837 anak pada usia 1-4 tahun, 1.192 anak pada usia 5-9 tahun dan 1.045 anak pada usia 10-14 tahun (Wardiyah, Setiawati \& Romayanti, 2016).

Demam pada anak sering menyebabkan kekhawatiran orang tua yang akhirnya menyebabkan tingginya penggunaan fasilitas pelayanan kesehatan (Peetoom et al., 2016). Studi yang dilakukan Yulandari, Mulyani\& Soedibyo (2017) di RSCM menyebutkan bahwa mayoritas (90\%) orang tua mengenal parasetamol sebagai antipiretik untuk anak, dan hanya $36,7 \%$ orang tua yang mendapatkan antipiretik tersebut berdasarkan resep dokter. Selain itu kecemasan yang berlebihan dapat memunculkan praktik agresif yang berbahaya pada anak, seperti over dosis penggunaan antipiretik (Patricia, 2014; Kelly et al, 2016; Yulandari, Mulyani \& Soedibyo, 2017). Deteksi suhu yang salah oleh perawat juga dapat menyebabkan keterlambatan dalam mencari perawatan medis, penegakan diagnostik dan akhirnya menunda perawatan (Batra, Saha \& Faridi, 2012). Penilaian suhu juga penting untuk keputusan keperawatan, diagnosa medis, dan perlu tidaknya pemeriksaan laboratorium spesifik dilakukan terkait penegakan diagnosa (Sund-Levander \& Grodzinsky, 2013; Niehues, 2013).

Memperoleh hasil pengukuran suhu yang andal merupakan komponen prosedur rutin yang dilakukan perawat hampir di semua area pelayanan keperawatan klinis pada anak. Agar asuhan keperawatan yang diberikan berkualitas, perawat anak harus dapat memanfaatkan perangkat pengukuran suhu yang tepat, akurat dan tidak membahayakan bagi klien (Opersteny et al, 2017). Teknik pengukuran suhu yang ideal adalah harus aman, mudah, non-invasif, efektif biaya, hemat waktu, dan harus benar-benar mencerminkan suhu tubuh inti "core temperature" (Batra, Saha \& Faridi, 2012). Termometer inframerah merupakan termometer non-invasif, tampaknya menjadi alternatif yang relatif baru dan populer untuk mendeteksi demam pada anak (Barbi et al, 2017).

Survei yang dilakukan baru-baru ini menyatakan bahwa selama delapan tahun berturut-turut, dari 216 responden dokter anak yaitu sebanyak 54\% menempatkan Infrared Temporal Artery Thermometer (TAT) sebagai metode pengukuran suhu yang paling banyak dipilih berdasarkan kemudahan penggunaannya, dan sebanyak $41 \%$ dokter anak memilih TAT sebagai termometer yang paling digemari dibandingkan dengan telinga, rektal, oral dan juga aksila. Inovasi TAT saat ini juga tersedia dalam bentuk terkoneksi secara otomatis dengan monitor vital sign yang terintegrasi dengan Electronic Medical Record (EMR/EHR) (Exergen Corporation, 2017).

Tujuan kajian ini adalah untuk menggali potensi penerapan perkembangan teknologi pengukuran suhudi Indonesia, khususnya pada area keperawatan anak di berbagai unit/fasilitas pelayanan keperawatan yang ada. Melalui penggunaan teknologi ini diharapakan mampu meningkatkan kualitas pelayanan dan kepuasan terhadap klien maupun keluarga.

\section{Temporal Artery Thermometer (TAT)}

Pengukuran suhu rektal tetap menjadi standar emas klinis untuk mendiagnosa demam pada bayi dan anak dibandingkan dengan dengan metode pengukuran yang lain (Hockenberry, 2017). Namun studi yang dilakukan oleh Batra \& Goyal (2013) menemukan bahwa Temporal Artery Temperature memiliki korelasi yang lebih baik dengan temperatur rektal, jika dibandingkan dengan pengukuran aksila dan timpani. Hal ini sejalan dengan riset Opersteny et al (2017) yang menyimpulkan bahwa jika dibandingkan dengan temperatur oral maupun aksila, hasil pengukuran TAT lebih akurat, lebih sensitif dan sesuai dengan harapan pasien dan keluarga. Beberapa pertimbangan yang menjadikan TAT sebagai peringkat teratas dalam metode pengukuran suhu pada bayi dan anak-anak berdasarkan evidence based practice, sebagai berikut:

\section{TAT Meningkatkan Rasa Nyaman dan Menurunkan Tekanan Psikologis/Emosional Anak Maupun Keluarga}

Meskipun temperatur rektal dianggap sebagai standar emas, namun juga memberikan masalah tersendiri termasuk ketidaknyamanan psikologis, adanya kemungkinan komplikasi seperti perforasi rektum, berisiko terkena kontaminasi silang, dan ada juga kemungkinan hasil dipengaruhi oleh adanya feses di rektum atau oleh aliran darah rektal. Selain itu anak cenderung agresif selama prosedur berlangsung sehingga detak jantung dan kecemasan menjadi meningkat, kurangnya privacy, serta memakan waktuterkait kegiatan melepaskan pakaian anak dalam prosedur pemeriksaannya (Hockenberry, 2017; Allegaert, Casteels, van Gorp, \& Bogaert, 2014; Reynolds et al, 2014; Moore, Carrigan, Solomon, \& Tart, 2014).

Penelitian Opersteny et al (2017), Forest et al (2017), dan Isler, Aydin, Guven, \& Gunay (2014) menyimpulkan bahwa jika dibandingkan 
dengan hasil pengukuran temperatur oral maupun aksila, perangkat TAT terbukti memberikan kualitas perawatan yang lebih tinggi dengan memberikan kenyamanan dan meningkatkan kepuasan klien dan keluarga, sebagai contoh TAT dapat menghemat waktu pengukuran suhu sehingga waktu menyusui ibu lebih lama. Pada pengukuran suhu aksila dibutuhkan kerjasama yang baik dengan membuka pakaian dan prosedur dilakukan dengan memegang erat tangan anak yang juga menimbulkan ketidaknyamanan (Hockenberry, 2017).

Pengukuran temperatur temporal dan tympani tidak memerlukan waktu yang lama dan kerjasama yang baik dengan klien jika dibandingkan dengan akses rektal, oral maupun aksila, sehingga kenyamanan penggunaan dirasakan oleh klien dan keluarga. Namun adanya kontroversi terkait penempatan probe tympani yaitu apakah pinna harus ditarik seperti cara yang mirip digunakan pada prosedur otoscopy, dengan demikian prosedur ini juga memberikan rasa tidak nyaman pada anak-anak (Hockenberry, 2017; Yang et al, 2016; Batra, Saha, \& Faridi, 2012).

\section{Keakuratan, Sensitifitas dan Kemudahan Pengukuran TAT (Temporal Artery Thermometer)}

Beberapa faktor yang mempengaruhi variasi termoregulasi antara individu satu dengan lainnya yaituusia, jenis kelamin, dan lokasi pengukuran (Sund-Levander \& Grodzinsky, 2013). Terkait keakuratan dan ketepatan pengukuran TAT pada bayi dan anak-anak telah dievaluasi melalui EBP dan hasilnya bervariasi. Sebagai contoh beberapa peneliti melaporkan bahwa TAT memberikan pengukuran yang andal, dapat dipercaya dan berkorelasi positif dengan termometer rektal dan termometer non-invasif yang lain (Opersteny et al, 2017; Goswami, Batra, Kurana, Dewan, 2017; Reynold et al, 2014; Isler, Aydin, Guven, \& Gunay, 2014; Batra \& Goyal, 2013; Bahorski et al., 2012). Sedangkan beberapa peneliti lain menyimpulkan bahwa TAT kurang meyakinkan atau memiliki korelasi yang belum sesuai dengan "core temperature" (Geijer, Udumyan, Lohse, \& Nilsagard, 2016; Patricia, 2014; Moore, Carrigan, Solomon, \& Tart, 2014; Kelechi, Benedict, Nwolisa, Ifeyinwa, \& Selin, 2014; Allegaert, Casteels, van Gorp, \& Bogaert, 2014; Odinaka, Edelu, Nwolisa, Amamilo, \& Okolo, 2014).

Studi yang dilakukan Bahorski et al (2012) pada anak usia 3 sampai 36 bulan, menunjukkan bahwa tidak ada perbedaan statistik yang signifikan antara hasil pengukuran temporal dan rektal temperatur. Sistematik review dan meta analisis yang dilakukan Geijer, Udumyan, Lohse, \& Nilsagard (2016) menyatakan bahwa TAT tidak cukup akurat untuk mengganti salah satu metode invasif yang mendekati "core temperature", namun akurasi TAT bisa menggantikan atau sama dengan termometer tympani. Serupa dengan hasil penelitian Allegaert, Casteels, van Gorp, \& Bogaert (2014) dan Brosinski, Valdez, Riddell, Riffenburgh (2017) yang menyatakan bahwa diantara beberapa pilihan termometer non-invasif, pengukuranarteri temporal menjadi yang terbaik kedua setelah pengukuran rektal, namun belum optimal bila dibandingkan dengan hasil pengukuran rektal.

Studi yang dilakukan Opersteny et al, (2017) membuktikan bahwa TAT lebih waspada terhadap akselerator demam dan setidaknya sama sensitifnya dengan termometer oral. Selain itu waktu respons TAT relatif cepat, efisien dan sederhana bagi praktisi kesehatan untuk digunakan jika dibandingkan dengan perangkat oral dan aksila. Termometer aksilaris dan oral dapat mengambil lebih dari 30 detik sampai 1 menit untuk membaca suhu, sedangkan TAT membutuhkan waktu sekitar 2-5 detik.

Keunggulannya temporal dan tympani temperatur adalah kemudahan akses situs, kecepatan mendapatkan hasil dan kemudahan teknik pengukuran serta masalah terkait dengan pengendalian infeksi tidak banyak dijumpai, jika dibandingkan dengan akses rektal, oral maupun aksila (Isler, Aydin, Guven, \& Gunay, 2014; Batra Saha, \& Faridi, 2012). Namun temperatur timpani memiliki tingkat kepekaan yangkurang memadai dan sulit digunakan pada anak-anak di bawah usia 2 tahun karena saluran telinga yang sempit dan hasil pengukuran menjadi terganggu dengan adanya serumen atau pada kondisi anak dengan infeksi telinga (otitis media), serta termometer ini sulit diposisikan dengan benarpada anak yang hiperaktif (Yang et al., 2016; Niehues, 2013; Batra, Saha, \& Faridi, 2012).

Suhu oral dapat menunjukkan perubahan yang cepat dari suhu tubuh inti, sehingga akurasinya bisa menjadi masalah (Batra, Saha \& Faridi, 2012). Beberapa faktor yang mempengaruhi suhu oral antara lain makan dan mengunyah, minuman panas atau dingin, bernapas dengan menggunakan mulut, dan suhu lingkungan. Selain itu kontra indikasi pengukuran suhu oral antaralain pada anak-anak dengan penurunan kesadaran, pemasangan oksigen, mengalami mucositis, menjalani operasi 
atau trauma pada mulut serta anak usia di bawah 5 tahun (Hockenberry, 2017).

Systematic review dan meta-analysis Niven, Gaudet, Laupland, Mrklas, Roberts, Stelfox (2015) menunjukkan bahwa di antara metode non-invasif, pengukuran aksila adalah yang paling tidak akurat, dengan selisih substansial. Beberapa pengukuran suhu aksila tidak konsisten dan tidak sensitif pada bayi dan anak diatas usia satu bulan (Reynolds et al, 2014; Stine, Flook, \& Vincze, 2012). Suhu aksila dapat dipengaruhi oleh perfusi perifer yang buruk, posisi, dan pakaian yang berefek pada hasil yang lebih rendah dari yang seharusnya (Hockenberry, 2017).

Kekurangan TAT tidak banyak, antara lain harganya relatif lebih mahal jika dibandingkan dengan termometer infrared dan digital lainnya. Selain itu adanya diaphoresis/keringat dapat mengganggu adhesi dan menyebabkan pendinginan kulit pada dahi yang mengenalkan kemungkinan suhu lebih rendah dari yang seharusnya, namun periode diaphoresis ini dapat diantisipasi dengan teknik pengukuran yang dilakukan sampai pada pelipis belakang telinga, karena area ini selalu menunjukkan tingginya aliran darah untuk pengukuran arteri (exergen corporation, 2017). Studi yang dilakukan Reynolds et al (2014), berhipotesis bahwa kehadiran kelembaban kulit/diaphoresis di daerah dahi selama pengukuran dapat mempengaruhi akurasi termometer arteri temporal. Penelitian sebelumnya belum mengevaluasi faktor ini sebagai sumber potensial untuk kesalahan pengukuran yang mempengaruhi akurasi perangkat. Penelitian selanjutnya yang disarankan yaitu memeriksa apakah kelembaban kulit mempengaruhi akurasi termometer arteri temporal (TAT). Serta membandingkan antara hasil pengukuran TAT dengan suhu tubuh inti "core temperature" (Opersteny et al, 2017).

\section{Deskripsi Non-Invasif Termometer: Temporal Artery Temperature (TAT) Terintegrasi dengan EMR/HER}

Temporal Artery Thermometer (TAT) merupakan perangkat sensor inframerah pemindai dahi untuk mendeteksi panas yang memancar dari kulit pada arteri temporal (Reynolds et al, 2014). Letaknya ideal di bagian depan dahi, sangat non-invasive, lebih mudah dan lebih nyaman untuk digunakan daripada jenis termometer lainnya. Metode penggunaannya cukup praktis dan sederhana yaitu dengan menempelkan sensor infrared scanner temporal pada tengah dahi (sambil menekan tombol scan) kemudian digeser melintasi dahi ke telinga dan berhenti pada bagian pelipis (belakang telinga) (Kyle \& Carman, 2013).

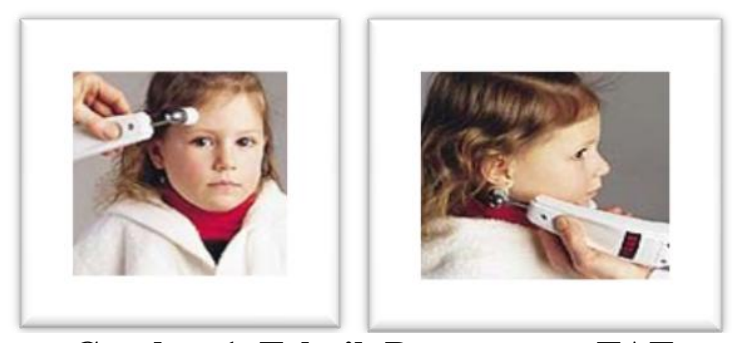

\section{Gambar 1. Teknik Penggunaan TAT}

Seperti yang kita ketahui bahwa tempat terbaik untuk mengukur suhu adalah pada pusat jantung, tapi ini bisa dilakukan hanya di bawah pengawasan dokter (prosedur invasif). Pengukuran suhu darah di arteri besar secara akurat mencerminkan suhu tubuh inti "core temperature". TAT mengukur suhu permukaan kulit di atas arteri temporal sebagai arteri utama di kepala. Arteri temporal terhubung ke jantung melalui arteri karotis, mengarah langsung dari aorta yang merupakan batang utama sistem arteri. Arteri ini menawarkan aliran darah konstan dan satu-satunya arteri yang diposisikan cukup dekat dengan permukaan kulit guna menyediakan akses yang dibutuhkan untuk melakukan pengukuran yang akurat (Hockenberry, 2017). Inilah yang menjadi dasar dan alasan memilih pengukuran suhu tubuh diatas arteri temporal.

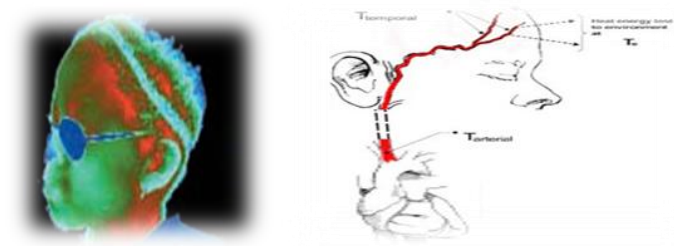

Gambar 2. Arteri temporalis

Penggunaan temporal arteri termometer memiliki banyak implikasi klinis positif sebagai termometer screening demam pada klien (neonatus, bayi dan anak), baik yang dirawat di tempat perawatan akut, unit perawatan gawat darurat dengan kebutuhan penanganan cepat dan tepat, perawatan bedah/injury ortopedi, maupun pada pemeriksaan suhu rutin pada klien rawat jalan dan rawat inap (Opersteny et al, 2017; Forest, Juliano, Conley, Cronyn, McGlynn, \& Auten, 2017; Brosinski,Valdez, Riddell, \& Riffenburgh, 2017; Goswami, Batra, Kurana, \& Dewan, 2017; Odinaka, Edelu, Nwolisa, Amamilo,\& Okolo, 2014). Selain itu, pengukuran infrared TAT memberikan kemudahan penggunaan, dan diharapkan akan dapat meningkatkan kualitas dan efisiensi asuhan 
keperawatan anak (Opersteny et al, 2017; Isler, Aydin, Guven, \& Gunay, 2014; Batra \& Goyal, 2013; Reynold et al, 2014; Odinaka, Edelu, Nwolisa, Amamilo, \& Okolo, 2014).

Salah satu jenis termometer infrared dengan metode pengukuran pada akses arteri temporal yang ditawarkan saat ini yaitu temporal scanner yang diproduksi oleh Exergen Corporation, dan saat ini dipasarkan untuk penggunaan konsumen diberbagai Negara Amerika Utara dan Eropa (Patricia, 2014). Ada tiga jenis produk TAT yang diperkenalkan oleh Exergen Corporation (2017) sebagai berikut:

\section{a. TAT 5000}

TAT-5000 didesain secara single tanpa terkoneksi dengan monitor, ditujukan untuk memudahkan dan memenuhi tuntutan tugas berat ditatanan perawatan berkinerja tinggi, terutama di unit gawat darurat. Namun demikian, dapat juga digunakan di unit perawatan akut lainnya seperti unit perawatan intensif (NICU, PICU), dan unit rawat inap.
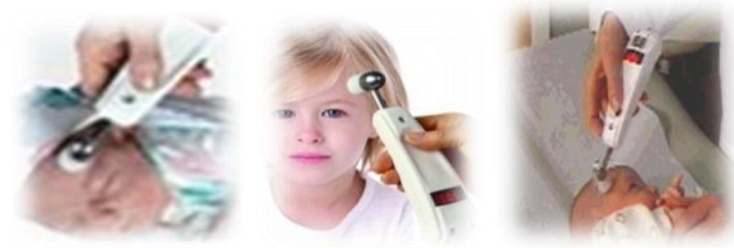

\section{Gambar 3. TAT 5000}

\section{b. TAT 5000S}

Exergen TAT-5000S Connected Model tersedia dalam bentuk terkoneksi langsung pada monitor vital sign, menghasilkan integrasi data pada EHR (Health Electronic Record). Alat ini juga dapat meningkatkan efisiensi, dapat digunakan hampir pada semua situasi perawatan klien.

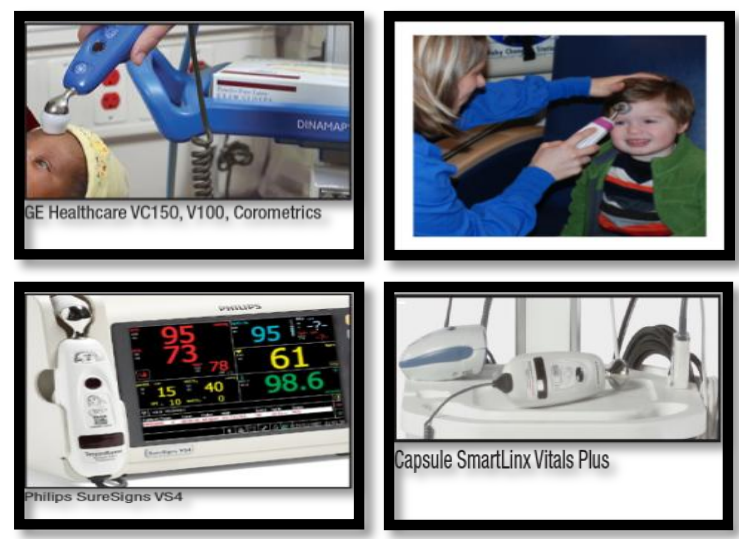

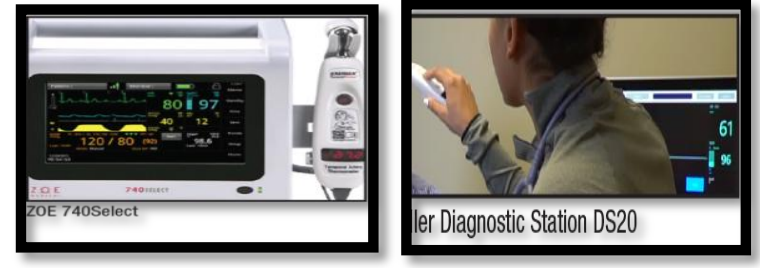

Gambar 4. TAT 5000S

\section{c. TAT 2000}

TAT-2000 adalah model ringkas yang ditujukan untuk penggunaan sehari-hari baik di rumah, sekolah, panti jompo serta di tempat pelayanan klinis lainnya yang biasanya digunakan sesekali saja.
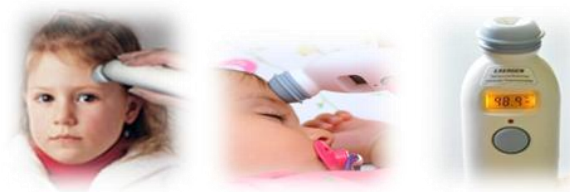

\section{Gambar 5. TAT 2000}

\section{Elektronic Medical Record (EMR)} merupakan catatan/rekam medis pasien yang dibuat dalam format digital yang mencakup berbagai informasi pribadi maupun klinis pasien. Pemanfaatan Sistem informasi kesehatan terkomputerisasi ini bertujuan untuk meningkatan kualitas perawatan klien, meningkatan efisiensi dan mengurangi biaya perawatan. Terkait kepentingan akademis, sejumlah besar informasi klinis yang tersimpan dalam database EMR sangat bermanfaat sekali untuk kegiatan penelitian. Dalam pelaksanaannya, ditemukan isu dan resiko terkait EMR terhadap praktik keperawatan saat ini yaitu sistem yang digunakan secara rutin oleh perawat untuk mendokumentasikan semua informasi klien ini, malah menimbulkan masalah tersendiri terhadap pelayanan keperawatan, dimana perawat memerlukan proses entri data yang memakan waktu cukup lama sehingga dapat mengurangi interaksi tatap muka antara pasien dan perawat (Alpert, 2016; Balestra, 2017).

Praktisi perawat harus mampu menerapkan praktik terbaik sebagai navigasi keberhasilan penggunaan EMR, penerapan strategi manajemen resiko untuk memastikan perawatan pasien lebih baik dan guna menghindari kejadian malpraktik (Balestra, 2017). Dengan adanya inovasi TAT yang terintegrasi dengan Elektronic Medical Record (EMR)/ Electronic Health Record (EHR), dimana hasil pengukuran suhu dapat terkoneksi langsung pada monitor vital sign dan data secara otomatis terkirim pada electronic medical records diharapkan dapat menjadi salah satu alternatif jawaban terkait isu dan resiko praktik 
EMR oleh perawat. Prosedur ini menjadikan pekerjaan perawat lebih cepat dan lebih mudah, sehingga mengurangi pekerjaan perawat dalam mencatat dan atau mengentri data yang cukup menyita waktu, sehingga hal ini sangat memungkinkan untuk dapat mengembalikan fokus tugas perawat kepada pelayanan terhadap pasien.

\section{PEMBAHASAN}

Kajian literatur ini, menunjukkan kelebihan bukti yang mendukung TAT sebagai termometer non-invasif yang akurat, sensitif dan nyaman digunakan pada bayi dan anak-anak. Kelebihan TAT dibandingkan dengan termometer jenis lain berdasarkan evidence based practice yang ada yaitu pertama TAT lebih aman digunakan, sebab termometer raksa dianggap berisiko beracun jika pecah. Kedua TAT lebih nyamandan dapat menurunkan tekanan psikologis/emosional pada anak dan keluarga. Meskipun temperatur rektal dianggap sebagai standar emas, namun juga memberikan masalah tersendiri termasuk ketidaknyamanan psikologis, adanya kemungkinan komplikasi seperti perforasi rektum, berisiko terkena kontaminasi silang, dan juga kemungkinan hasil dipengaruhi oleh adanya feses di rektum, dan/atau oleh aliran darah rektal. Selain itu pada metode rektal anak cenderung agresif selama prosedur berlangsung sehingga detak jantung dan kecemasan menjadi meningkat, kurangnya privacy, serta memakan waktu terkait kegiatan melepaskan pakaian anak dalam prosedur pemeriksaannya. Sedangkan pada termometer timpani yang sama-sama cepat, mudah diakses, dan nyaman untuk anak-anak, namun terkait kepekaannya tidak memadai, dan menjadi terganggu dengan adanya serumen atau pada kondisi anak dengan infeksi telinga (otitis media), serta termometer ini sulit diposisikan dengan benar pada anak yang hiperaktif. Kelebihan ketiga yaitu terkait kepekaan (sensitifitas), keakuratan, dan kemudahan TAT dalam hal pengukuran jika dibandingkan dengan termometer jenis lain, serta waktu pengukuran suhu yang relatif singkat yaitu hanya membutuhkan \pm 6 detik dalam setiap pengukuran. Adapun kekurangan TAT tidak banyak antara lain harganya relatif lebih mahal jika dibandingkan dengan termometer digital serta adanya diaphoresis/keringat berlebihan yang dapat mempengaruhi keakuratan (namun hal ini masih dapat diatasi dengan terlebih dulu menyeka keringat sebelum pengukuran dilakukan).
TAT juga merupakan salah satu metode non-invasif termometer yang mengusung konsep atraumatic care sebagai bentuk perawatan terapeutik dengan mengurangi dampak psikologis pada anak dan keluarga terhadap prosedur tindakan yang dilakukan oleh perawat. Kehadiran TAT ini juga memberikan kepuasan tersendiri kepada keluarga terhadap asuhan keperawatan yang diberikan, dimana peran keluarga dalam perawatan anak dirumah sakit begitu penting, setiap asuhan pada anak yang dirawat di rumah rumah sakit memerlukan keterlibatan orang tua didalammya yang merupakan konsep Familly Centered Care (FCC).

Pelayanan prima keperawatan anak profesional membutuhkan termometer noninvasif berkualitas tinggi untuk mendapatkan manfaat klinis terkait akurasi, kenyamanan dan kemudahan penggunaan (Hockenberry, 2017). Berdasarkan studi literatur yang ada, Temporal Artery Thermometer menjawab tantangan tersebut dengan menjadi inovasi produk transformasi profesional keperawatan yang menjadikan pekerjaan perawat lebih mudah dan lebih efektif. Implementasi TAT yangterintegrasi dengan EMR/HER diharapkan akan meningkatkan kualitas asuhan keperawatan anak dengan memanfaatkan penggunaan dan kemajuan catatan medis elektronik terhadap hasil pengukuran suhu klien (Exergen Corporation, 2017).

Dalam implementasi TAT ini juga menjadi penting untuk memperoleh hasil pengukuran suhu yang akurat, sehingga semua faktor yang mempengaruhi pengukuran suhu juga harus dipertimbangkan. Adapun faktor-faktor yang mempengaruhi pengukuran suhu meliputi faktor fisiologis (tempat pengkuran, waktu, aktivitas, jenis kelamin dan umur klien), faktor teknis, teknik penggunaan, serta kalibrasi dan pemeliharaan (Sund-Levander \& Grodzinsky, 2013; Davie \& Amoore, 2010). Analisa beberapa faktor diatas terkait pengukuran suhu TAT, sebagai berikut:

\section{Faktor Fisiologis}

Secara fisiologis suhu dipengaruhi oleh tempat pengukuran, waktu pengukuran, aktivitas, jenis kelamin dan umur, sehingga belum dapat disimpulkan adanya metode non-invasif pengukuran suhu yang benar-benar tepat dan akurat baik melalu oral, timpani, aksila, temporal maupun rektal (Sund-Levander \& Grodzinsky, 2013; Davie \& Amoore, 2010). Namun demikian TAT memiliki beberapa kelebihan antara lain terkait lokasi pengukuran pada dahi yang mudah 
dijangkau, memberikan kenyaman, bebas dari rasa nyeri, sehingga dapat menurunkankan tekanan psikologis/emosional anak dan juga keluarga.

\section{Faktor Teknis}

TAT mendapatkan hasil pengukuran suhu dengan metode yang lebih peka/sensitif dari pada metode non-invasif lainnya. Selain itu TAT lebih aman digunakan dibandingkan dengan termometer raksa, sebab termometer raksa dianggap berisiko beracun jika pecah. Untuk tujuan masa depan terhadap pemantauan suhu tubuh di rumah sakit terkait keakuratan dan kenyamanan perangkat digital diharapkan dapat lebih ditingkatkan lagi dengan penyempurnaan teknologi, menurunkan biaya, serta kesempatan efisien waktu bekerja bagi profesional medis (Kumana, 2017; Sund-Levander \& Grodzinsky, 2013).

\section{Faktor Teknik Penggunaan}

Cara penggunaan alat yang tepat akan meminimalkan efek ketidakakuratan hasil pengukuran. Teknik penggunaan TAT lebih mudahjika dibandingkan dengan termometer non-invasif jenis lain, namun hal yang perlu diperhatikan terkait teknik penggunaan TAT ini adalah, dengan memastikan bahwa alat benarbenar digeserkan melintasi arteri temporal yaitu melintasi temporal dahi ke telinga dan berhenti pada bagian pelipis (belakang telinga). Penggunaan TAT bervariasi diantara praktisi, teknik penggunaannya pada anak yang sehat, sakit maupun cidera juga menjadi sangat penting, sehingga perawat perlu menggunakan perangkat sesuai dengan pedoman pabrik agar didapatkan penilaian suhu yang andal (Moore, Carrigan, Solomon, \& Tart, 2014). Disinyalir isu penurunan minat terhadap teknologi TAT ini diterapkan di klinik dan RS di Indonesia, mungkin disebabkan adanya kesalahan terkait teknik penggunaan alat yang mempengaruhi hasil pengukuran.Oleh karena itu penting bagi perawat untuk dilatih dalam penggunaan termometer arteri temporal ini secara benar.

\section{Kalibrasi dan Pemeliharaan Alat TAT}

Termometer dikalibrasi secara rutin dengan menggunakan peralatan dan prosedur yang sesuai dengan kriteria dan standar nasional dan internasional. Provider harus memberikan bimbingan protokol dan instrument kalibrasi untuk mengaktifkan verifikasi akurasi termometer. Termometer juga harus dibersihkan secara teratur dan dipelihara pemakaiannya untuk memastikan bahwa alat tersebut memberikan hasil yang akurat dan tepat (Davie \& Amoore, 2010). TAT didesain untuk mudah dibersihkan dan memungkinkan pilihan probe menggunakan penutup sekali pakai (disposible) atau membersihkan dengan menggunakan disinfektan setelah dipakai pasien lain atau dengan kata lain alat ini juga dapat menghemat biaya dengan mengurangi penggunaan penutup probe.

Dokumentasi pada metode pengukuran suhu lainnya menuntut perawat untuk melakukan pencatatan atau mengentri secara manual, namun pada TAT yang terkoneksi pada monitor vital sign data secara otomatis dikirimkan ke electronic medical record, sehingga inilah yang menjadikan TAT sebagaitrend pilihan perawat saat ini (Exergen Corporation, 2017). Gawai Sehat (11 November 2016) mencatat daftar beberapa RS di Indonesia yang sudah menerapkan Rekam Medis Elektronik (RME) antara lain RSCM, Eka Hospital, RS Pondok Indah, RSA UGM, RS Panti Rapih, RSUD Margono, RS Paru Jember, dan RSUD Dr Moewardi serta beberapa RS lain yang mungkin belum tercatat. Potensi pengembangan teknologi TAT terintegrasi dengan EMR/EHR tergantung dari telah sejauh mana implementasi EMR di RS Indonesia ini telah diterapkan, apa saja fungsionalitas dari rekam medis elektronik, apakah sudah sudah menerapkan CPOE (computerized physician order entry), dan apakah sudah terpadu dengan vital sign, laboratorium, radiologi, farmasi, dan lain-lain. Adapun tantangan penggunaan sistem ini di Indonesia antara lain masih banyaknya staf medis yang tidak terlatih dalam penggunaan komputer, tingginya biaya yang dikeluarkan dalam pengadaan awal sistem dan juga pemeliharaan alatnya. Selain itu, masalah yang potensial terjadi yaitu kemungkinan adanya hacker yang dapat mengakses sistem (Balestra, 2017). Namun demikian, sistem ini sangat penting untuk dapat memperbaiki kualitas perawatan pasien kearah yang lebih baik lagi, sehingga langkah awal penggunaan dan pengembangannya di Indonesia juga menjadi penting untuk dipertimbangkan.

\section{SIMPULAN}

Beberapa penelitian yang ada merekomendasikan penggunaan TAT sebagai termometer yang akurat, aman, dan nyaman digunakan dalam pemeriksaan suhu rutin pada anak. Selain itu TAT juga direkomendasikan 
sebagai metode pengukuran suhu yang dapat diterima sebagai pengganti termometer noninvasif lainnya, serta menjadikannya sebagai salah satu inovasi dalam bidang keperawatan anak diberbagai tatanan pelayanan kesehatan (unit emergency, unit intensive care, rawat jalan, rawat inap, maupun digunakan di rumah oleh orang tua).

Inovasi TAT yang terintegrasi dengan EMR/EHR mendukung tuntutan penggunaan kemajuan catatan medis elektronik terhadap hasil pengukuran suhu, dimana diperolehnya efisiensi waktu bekerja, sehingga mengembalikan fokus tugas perawat kepada peran pemberian asuhan, dan pelayanan yang prima terhadap klien. Selain

\section{DAFTAR PUSTAKA}

Allegaert, K., Casteels, K., Van Gorp, I., \& Bogaert, G. 2014. Tympanic, infrared skin, And temporal artery scan thermometers compared with rectal measurement in children: A real-life assessment. Current Therapeutic Research-Clinical and Experimental, 76, 34-38. https://doi.org/10.1016/j.curtheres.2013.11. 005

Alpert, J. 2016. The Electronic Medical Record in 2016: Advantages and disadvantages. Digital Medicine, 2(2), 48.https://doi.org/10.4103/22268561.189504

Balestra, M. L. 2017. Electronic Health Records: Patient Care and Ethical and Legal Implications for Nurse Practitioners. The Journal for Nurse Practitioners, 13(2), 105-111. https://doi.org/10.1016/j.nurpra.2016.09.01 0

Bahorski, J., Repasky, T., Ranner, D., Fields, A., Jackson, M., Moultry, L., ... Sandell, M. (2012). Temperature Measurement in Pediatrics: A Comparison of the Rectal Method Versus the Temporal Artery Method. Journal of Pediatric Nursing, 27(3),

243-247. https://doi.org/10.1016/j.pedn.2010.12.015

Barbi, E., Marzuillo, P., Neri, E., Naviglio, S., \& Krauss, B. 2017. Fever in Children: Pearls and Pitfalls. Children, 4(9), 81.https://doi.org/10.3390/children409008 1

Batra, P., \& Goyal, S. 2013. Comparison of rectal, axillary, tympanic, and temporal artery thermometry in the pediatric emergency room.Pediatric Emergency itu TAT mengusung konsep keperawatan anak yaitu atraumatic care sebagai bentuk perawatan terapeutik pada anak, dan family centered care dengan memberikan kepuasan tersendiri kepada keluarga sebagai fokus asuhan keperawatan.Hal inilah yang menjadikan TAT sebagai peringkat teratas sebagai metode pengukuran suhu pada bayi dan anak, dibandingkan dengan metode pengukuran suhu lainnya. Perawat anak di Indonesia perlu melihat bukti, mempelajari teknologi baru, dan mengimplementasikan secara nyata penerapan evidence based, dengan harapan dapat meningkatkan kualitas asuhan keperawatan terhadap klien dan keluarga.

Care, 29(1), 63-6.

https://doi.org/10.1097/PEC.0b013e31827 b5427

Batra, P., Saha, A., \& Faridi, M. M. 2012. Thermometry in children.Journal of Emergencies, Trauma, and Shock, 5(3), 246.https://doi.org/10.4103/09742700.99699

Brosinski, C., Valdez, S. Riddell, A., Riffenburgh, R.H. 2017. Comparison of Temporal Artery Versus Rectal Temperature in Emergency Department Patients Who Are Unable to Participate in Oral Temperature Assessment. Journal of Emergency Nursing, 1-7. https://doi.org/10.1016/J.JEN.2017.04.015

Davie, A., \& Amoore, J. 2010. Best practice in the measurement of body temperature. Nursing Standard (Royal College of Nursing (Great Britain): 1987), 24(42), 42-49.

https://doi.org/10.7748/ns2010.06.24.42.42 .c7850

Exergen Corporation. 2017. Pediatricians choose temporal artery thermometer as top pick among temperature taking methods. (2017, Sep 12). NASDAQ OMX's News Release Distribution Channel Retrieved from https://search.proquest.com/docview/1937 642980? accountid $=17242$

Exergen Corporation. 2017. Survey Says Over 90 Percent of Nurses Prefer Thermometers Connected to Vital Signs Monitors for Convenience and Accuracy. Watertown: Globe Newswire. Terbit 31 Agustus 2017. http://www.exergen.com/medical/surveysays-90-percent-nurses-preferthermometers-connected-vital-signs- 
monitors.pdf

Forrest, A. J., Juliano, M. L., Conley, S. P., Cronyn, P. D., McGlynn, A., \& Auten, J. D. 2017.Temporal artery and axillary thermometry comparison with rectal thermometry in children presenting to the emergency department. American Journal of Emergency Medicine, 4-7. https://doi.org/10.1016/j.ajem.2017.06.017

Gawai Sehat. 2016. Daftar RS di Indonesia yang Telah Menerapkan Rekam Medis Elektronik. Gawai Sehat Online. Terbit tanggal $11 \quad$ November 2017. darihttps://gawaisehat.com (Diakses tanggal 23 Oktober 2017)

Geijer, H., Udumyan, R., Lohse, G., \& Nilsagård, Y. 2016. Temperature measurements with a temporal scanner: systematic review and meta-analysis.

https://doi.org/10.1136/bmjopen-2015009509

Goswami, E., Batra, P., Khurana, R., \& Dewan, P. 2017. Comparison of Temporal Artery Thermometry with Axillary and Rectal Thermometry in Full Term Neonates.Indian Journal of Pediatrics, 84(3), 195-199. https://doi.org/10.1007/s12098-016-2259-z

Hockenberry, M., \& Wilson, D., Rodger, C.C., 2017. Wong's essential of pediatric nursing. $8^{\text {th }}$ ed. St. Louis Missouri: Elsevier

Işler, A., Aydin, R., Güven, Ş. T., \& Günay, S. 2014. Comparison of temporal artery to mercury and digital temperature measurement in pediatrics.International Emergency Nursing, 22(3), 165168.htts://doi.org/10.1016/j.ienj.2013.09.0 03

Kelechi, O., Benedict, E., Nwolisa, E., Ifeyinwa, A., \& Seline, O. 2014. Acceptance of temporal artery thermometry by Nigerian mothers: A comparison with the traditional methods. Pan African Medical Journal, 19.https://doi.org/10.11604/pamj.2014.19. 263.2899

Kelly, M., McCarthy, S., O'Sullivan, R., Shiely, F., Larkin, P., Brenner, M., \& Sahm, L. J. 2016. Drivers for inappropriate fever management in children: a systematic review. International Journal of Clinical Pharmacy, 38(4), 761-770. https://doi.org/10.1007/s11096-016-0333-2

Kumana, C. 2017. Minimising the costs of temperature monitoring in hospitals.Postgraduate Medical Journal, 93(1104), 580-580. https://doi.org/10.1136/postgradmedj2017-134795

Kyle, T.,\& Carman, S. 2013. Essential of pediatric nursing (2nd ed.). Philadelphia: Wolter Kluwer Health.

Moore, A. H., Carrigan, J. D., Solomon, D. M., \& Tart, R. C. 2015. Temporal Artery Thermometry to Detect Pediatric Fever. Clinical Nursing Research, 24(5), 556563.

https://doi.org/10.1177/105477381455748 1

Niehues, T. 2013. Das fiebernde kind: Diagnostisches vorgehen und behandlung. Deutsches Arzteblatt International, 110(45), 764-774. https://doi.org/10.3238/arztebl.2013.0764

Niven, D. J., Gaudet, J. E., Laupland, K. B., Mrklas, K. J., Roberts, D. J., \& Stelfox, H. T. 2015. Accuracy of peripheral thermometers for estimating temperature: A systematic review and meta-analysis. Annals of Internal Medicine, 163(10), 768-777. https://doi.org/10.7326/M151150

Odinaka, K. K., Edelu, B. O., Nwolisa, C. E., Amamilo, I. B., \& Okolo, S. N. 2014. Temporal artery thermometry in children younger than 5 years: a comparison with rectal thermometry. Pediatric Emergency Care, 30(12), 867-870. https://doi.org/http://dx.doi.org/10.1097/PE C. 0000000000000289

Opersteny, E., Anderson, H., Bates, J., Davenport, K., Husby, J., Myking, K., \& Oron, A. P. 2017. Precision, Sensitivity and Patient Preference of Non-Invasive Thermometers in a Pediatric Surgical Acute Care Setting.Journal of Pediatric Nursing, 35, 36-41. https://doi.org/10.1016/j.pedn.2017.02.003

Patricia, C. 2014. Evidence-Based Management of Childhood Fever: What Pediatric Nurses Need to Know.Journal of Pediatric Nursing, 29(4), 372-375. https://doi.org/10.1016/j.pedn.2014.02.007

Peetoom, K. K. B., Ploum, L. J. L., Smits, J. J. M., Halbach, N. S. J., Dinant, G.-J., \& Cals, J. W. L. 2016. Childhood fever in well-child clinics: a focus group study among doctors and nurses. BMC Health Services Research, 16(1), 240.https://doi.org/10.1186/s12913-0161488-1

Reynolds, A. M., Bonham, L., Gueck, M., Hammond, K., ... Craft, M. 2014. Are Temporal Artery Temperatures Accurate 
Enough to Replace Rectal Temperature Measurement in Pediatric ED Patients? YMEN, $40(1), \quad 46-50$. https://doi.org/10.1016/j.jen.2012.07.007

Sullivan, J. E., \& Farrar, H. C. 2011. Fever and Antipyretic Use in Children. Pediatrics, $127(3)$, 580-587. https://doi.org/10.1542/peds.2010-3852

Sund-Levander, M., \& Grodzinsky, E. 2013. Assessment of body temperature measurement options.British Journal of Nursing, 22(16), 942,944950.https://doi.org/10.12968/bjon.2013.22. 16.942

Stine, C. A., Flook, D. M., \& Vincze, D. L. 2012. Rectal Versus Axillary Temperatures: Is There a Significant Difference in Infants Less Than 1 Year of Age? Journal of Pediatric Nursing, 27(3), 265-270. https://doi.org/10.1016/j.pedn.2011.04.004

Setyowati, L. 2013. Hubungan Tingkat Pengetahuan Orang Tua dengan Penanganan Demam pada Anak Balita di Kampung Bakalan Kadipiro Banjarsari Surakarta. http://stikespku.com/digilib/files/disk1/1/st ikes\%20pku--linasetyow-44-120101292.pdf

Wardiyah, A., Setiawati, \& Romayanti, U. 2016. Perbandingan Efektifitas Pemberian Kompres Hangat Dan Tepid Sponge Terhadap Penurunan Suhu Tubuh Anak Yang Mengalami Demam Di Ruang Alamanda RSUD dr. H. Abdul Moeloek Provinsi Lampung Tahun 2015. Kesehatan Holistik, 10(1), 36-44.

Yang, W., Kuo, H., Lin, C., Wu, K., Chang, Y., Chen, C., \& Wu, H. 2016. Tympanic temperature versus temporal temperature in patients with pyrexia and chills. Medicine, 95(44), 1-6. https://doi.org/10.1097/MD.000000000000 52.

Yulandari, I., Mulyani, D. I., \& Soedibyo, S. 2017. Persepsi Orang Tua Mengenai Demam dan Penggunaan Antipiretik: Studi Potong Lintang di RSUD Malingping dan RSUPN Cipto Mangunkusumo. Hasil Penelitian, 44(10), 677-683. 